\title{
GREEN CORRIDORS: POTENSI PENINGKATAN RUANG TERBUKA HIJAU PUBLIK RAMAH DI KOTA PADAT (STUDI KASUS KOTA MALANG)
}

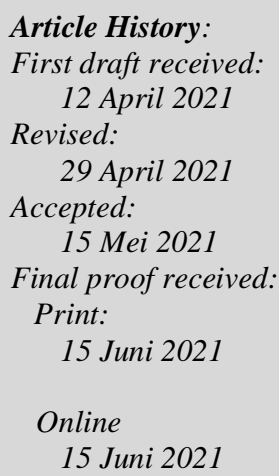

Jurnal Arsitektur ZONASI is indexed and listed in several databases:

\section{SINTA 4 (Arjuna)}

GARUDA (Garda Rujukan Digital) Google Scholar

Dimensions oneSearch

BASE

Member:
Crossref
RJI
APTARI
FJA (Forum Jurna Arsitektur)
IAI
AJPKM

\author{
Carissa Dinar Aguspriyanti ${ }^{1}$ \\ ${ }^{1}$ Universitas Internasional Batam, Kota Batam, Indonesia \\ Jalan Gajah Mada, Kota Batam, Kepulauan Riau 29442 \\ Email: carissa@uib.ac.id
}

\begin{abstract}
Urban streets, as the main element which covers nearly one-third of city landscapes, can be considerably transformed into green corridors to address green space shortage in densely populated cities that have limited open space due to massive development. On the other hand, urban streets are capable of acting as public spaces. This quantitative and qualitative research, which takes a case study in one of the dense cities in Indonesia, which is Malang City, aims to analyse the possibility of creating green corridors as sociable public spaces to do social activities, particularly in commercial areas. Through theoretical study and best-practices analysis, the main design principles of green corridors and the criteria of sociable public spaces were obtained. Then, according to the survey and questionnaire findings, it can be concluded that green corridors are potentially able to be sociable public spaces whilst playing a pivotal role in increasing green space coverage in dense cities. All those key findings were subsequently translated into a design guideline of green corridor for the selected case study site.
\end{abstract}

Keywords: green corridors; green open spaces; sociable public spaces; dense cities

\begin{abstract}
Abstrak: Jalan-jalan perkotaan, sebagai infrastruktur utama yang mencakup sekitar sepertiga dari lanskap kota, dapat dipertimbangkan untuk dijadikan koridor hijau guna menjawab isu kurangnya ketersediaan ruang terbuka hijau di kota-kota padat, yang notabene memiliki keterbatasan ruang terbuka akibat pembangunan yang masif. Di sisi lain, jalan perkotaan tersebut juga mampu berperan sebagai ruang publik. Penelitian kuantitatif dan kualitatif yang mengambil studi kasus di salah satu kota padat di Indonesia, yaitu Kota Malang, ini bertujuan untuk menganalisis potensi perwujudan koridor hijau sebagai ruang publik yang ramah untuk melakukan aktivitas sosial, khususnya di kawasan komersial. Melalui studi teoritis and analisis best-practices, ditemukan prinsip-prinsip desain utama koridor hijau dan kriteria ruang publik yang ramah. Selanjutnya, dari hasil survey dan kuesioner dapat disimpulkan bahwa koridor hijau berpotensi menjadi ruang publik yang ramah sekaligus memainkan peran penting dalam meningkatkan cakupan ruang hijau di kota-kota yang padat. Semua temuan utama tersebut kemudian diterjemahkan ke dalam sebuah pedoman desain koridor hijau untuk site studi kasus terpilih.
\end{abstract}

Kata Kunci: koridor hijau; ruang terbuka hijau; ruang publik ramah; kota padat

\section{Pendahuluan}

Fenomena kecenderungan meningkatnya level kepadatan suatu kota akibat pembangunan yang masif, menyebabkan minimnya ketersediaan ruang terbuka hijau di kota tersebut. Penurunan total cakupan ruang terbuka hijau memang telah terbukti memiliki kaitan dengan kepadatan kota yang cenderung tinggi (Jenks \& Jones, 2010). Menemukan ruang untuk membuat taman di kota-kota dengan kepadatan tinggi merupakan hal yang tidak mudah dan dapat menelan biaya yang tidak sedikit, sehingga berpotensi menurunkan kualitas hidup masyarakatnya karena keterbatasan akses terhadap area hijau (Byrne \& Rupprecht, 2014). Faktanya, terdapat peluang yang signifikan untuk menambahkan elemen hijau di lingkungan perkotaan, mulai dari penghijauan bangunan hingga penghijauan jalan. 
Baik Pujol dan Brenner menegaskan bahwa akan jauh lebih mudah untuk menambah dan meningkatkan ruang hijau dari infrastruktur yang sudah ada (jalan perkotaan, saluran air, dan atap) di kota-kota padat (The Nature of Cities, 2014). Jalan perkotaan sebagai ruang terbuka yang dapat ditemukan di mana-mana merupakan elemen utama kota yang mencakup sekitar sepertiga dari lanskap perkotaan (Das, 2006). Dengan demikian, potensi transformasi jalan perkotaan menjadi sebuah koridor hijau sebagai salah satu upaya untuk mengintegrasikan ruang terbuka hijau dengan infrastruktur yang sudah ada, dapat dipertimbangkan untuk mengatasi ruang terbuka hijau (RTH) yang tidak mencukupi di daerah perkotaan yang padat.

Peran jalan sebagai ruang publik kota yang mampu melayani aktivitas sosial penggunanya juga perlu diperhatikan. Tidak sedikit penelitian yang menunjukkan peran jalan permukiman dalam mendukung aktivitas sosial penduduknya. Namun, bagaimana hal tersebut dapat berlaku di jalan perniagaan yang notabene juga dipenuhi dengan aktivitas sosial dan sejauh mana prinsip koridor hijau dapat dikendalikan untuk mendukung sociability di jalan tersebut. masih menjadi sebuah pertanyaan. Jawaban dari pertanyaan ini akan dapat memberikan gambaran potensi penyediaan koridor hijau dalam menciptakan ruang terbuka hijau publik yang ramah sembari mencoba mengatasi isu minimnya RTH di kota-kota padat, seperti salah satunya di Kota Malang, Indonesia.

\subsection{Koridor Hijau (Green Corridors)}

Di samping memiliki pengaruh positif yang besar terhadap lingkungan, Appleton berpendapat bahwa koridor hijau dapat membantu melayani berbagai macam aktivitas rekreasi, menawarkan akses jalan yang nyaman dari jalan setapak menuju ke fungsi ruang lain seperti ruang terbuka publik (Groome, 1990). Transportasi publik dan pejalan kaki juga dapat difasilitasi di sepanjang rute. Selain itu, tujuan lain juga dapat dicapai melalui pembuatan koridor hijau di lingkungan perkotaan. Koridor ini dapat melibatkan desain lanskap untuk menciptakan hubungan antara sumber daya alam dan budaya. Misalnya, Kjer menunjukkan bahwa jalanjalan sempit ditransformasi menjadi koridor hijau di lingkungan padat di Los Angeles dapat menjadi ruang publik ramah yang mengundang untuk berkumpul dan berekreasi dengan memasang ornamen seni komunitas serta menanam elemen lanskap alami berupa tanaman yang dapat dikonsumsi (edible landscapes) (The Nature of Cities, 2014). Dengan demikian, aspek fisik yang terlihat dan lanskap yang mudah dikenali tersebut berpotensi disediakan oleh koridor hijau (Viles \& Rosier, 2001). Kedua hal tersebut merupakan faktor kunci dalam meningkatkan sense of place. Dengan kata lain, koridor hijau mampu memberikan kontribusi pada citra kota, membuatnya lebih menarik. Mengintegrasikan pemenuhan kebutuhan lingkungan dan sosial adalah kunci keberhasilan dari koridor hijau. Berdasarkan studi dari Das (2006), Perry (2010), dan The Nature of Cities (2014), dapat dirumuskan prinsip desain utama dari koridor hijau (Tabel 1).

Tabel 1. Prinsip Desain Koridor Hijau

\begin{tabular}{|l|l|}
\hline \multicolumn{1}{|c|}{ Prinsip } & \multicolumn{1}{c|}{ Deskripsi } \\
\hline Naturalization & $\begin{array}{l}\text { - Menciptakan konektivitas ekologis } \\
\text { - Membawa elemen alam (hijau) ke jalan } \\
\text { - Menciptakan berbagai lapisan vegetasi } \\
\text { - Membawa keanekaragaman tumbuhan }\end{array}$ \\
\hline Health & - Menciptakan area terapeutik \\
\hline Regulatory & $\begin{array}{l}\text { - Memberikan efek ketenangan } \\
\text { - Memaksimalkan kenyamanan }\end{array}$ \\
\hline Singular & $\begin{array}{l}\text { - Menghadirkan lanskap menarik yang dapat dinikmati secara } \\
\text { visual maupun fisik, serta mudah diidentifikasi }\end{array}$ \\
\hline Accesibility & - Meningkatkan nilai warisan alam dan budaya kota \\
\hline Diversity & - Menawarkan banyak pilihan transportasi (jika memungkinkan) \\
\hline $\begin{array}{l}\text { Informative/ } \\
\text { Educational }\end{array}$ & - Melayani beragam lapisan masyarakat (social diversity) \\
\hline
\end{tabular}

Sumber: Penulis, 2021

Selain berupaya mencapai tujuan mobilitas dan keselamatan, tidak sedikit jalan perkotaan yang menunjukkan bahwa mereka juga dapat memberikan manfaat terhadap lingkungan dan kelayakan hidup (liveability) di kota tersebut. Das (2006) mencoba memadukan siklus hidrologi alami dalam desain urbanscape dengan menyoroti tiga fitur utama jalan hijau yaitu pengolahan air, ruang multi guna, dan permukaan yang 
permeabel. Elemen penting lainnya, jika memungkinkan, adalah mengurangi lebar jalan sebagai upaya meminimalisir area kedap air yang tidak perlu (Lukes et al., 2008). Di samping itu, elemen jalan lain seperti jalur pejalan kaki dan pesepeda, jalur parkir dan jalur transit, berbagai jenis pohon trotoar, dan fasilitas air hujan yang bervegetasi dapat ditambahkan di sepanjang jalan (Lukes et al., 2008; Perry, 2010; Säumel et al., 2016). Meskipun demikian, proses alih fungsi jalan perkotaan menjadi koridor hijau ini dinilai membutuhkan perhatian lebih pada beberapa aspek. Prinsip desain koridor hijau mungkin perlu diterapkan secara berbeda tergantung pada lokasi, karena setiap tempat memiliki kondisi yang berbeda-beda. Perry (2010), bagaimanapun, mengungkapkan bahwa prinsip desain koridor hijau di area komersial hampir serupa dengan prinsip desain koridor hijau pada umumnya.

Ada batasan wajar yang membuat koridor hijau kurang dianggap sebagai solusi paling umum untuk masalah ruang terbuka hijau (RTH) hingga saat ini. Pertama, kemungkinan timbulnya konflik antara pengguna atau bahkan antara kebutuhan manusia dan ekologis alam dapat menghambat realisasi koridor hijau (Everett et al., 2018; Groome, 1990). Konflik ini berkaitan dengan pemanfaatan ruang. Misalnya, jalan di area komersial, orang yang memiliki bisnis di jalan tersebut tidak menyukai kenyataan bahwa koridor hijau menghabiskan ruang parkir untuk lansekap alaminya, yang berarti lebih sedikit ruang parkir untuk pelanggan mereka. Selain itu, khususnya di Indonesia, trotoar di jalan perniagaan sering dijadikan tempat berjualan barang atau bahkan parkir. Kedua, tingginya volume lalu lintas setiap hari juga mempengaruhi ketersediaan ruang di jalan untuk penghijauan. Tantangan ketiga bisa jadi berkaitan dengan persyaratan menjadi atraktif, karena orang tidak datang ke tempat secara spontan. Penempatan atribut atau elemen hijau di sepanjang jalan juga harus dipertimbangkan. Seperti yang disampaikan oleh Wolf (2005), terkait dengan penempatan pepohonan di trotoar kawasan komersial, yang menjadi perhatian utama pedagang adalah resiko berkurangnya visibilitas etalase dan papan nama. Selain itu, dengan kecenderungan perawatan yang buruk justru dapat membuat koridor hijau beresiko menurunkan kualitas lingkungan. Oleh sebab itu, dukungan publik harus diperoleh dari awal untuk memastikan kolaborasi dan kemauan untuk menjaga ruang bersama, untuk mencapai sistem pengelolaan dan pemeliharaan yang berkelanjutan.

\subsection{Jalan Sebagai Ruang Publik yang Ramah (Sociable Public Spaces)}

Jalan dapat memainkan peran penting dalam infrastruktur perkotaan. Bukan hanya sebagai pembatas dan penghubung jalan, tetapi jalan juga dapat berperan sebagai ruang sosial dengan karakter atau citra tempat yang kuat dan sangat berkaitan dengan kehidupan publik (Carmona et al., 2003; Jacobs, 1993; Mehta, 2013; Mordon, 1987; Säumel et al., 2016). Jalan sebagai ruang publik yang ramah (sociable public spaces) merupakan ruang yang memberikan kesempatan bagi orang untuk terlibat dalam berbagai macam aktivitas (individu maupun kelompok). Kebutuhan rekreasi, komersial, dan sosial masyarakat pun juga dapat dipenuhi oleh tipe jalan yang ramah ini. Berdasarkan studi dari Public Spaces (n.d.) and Mehta (2013), ditemukan bahwa ruang yang ramah memiliki beberapa kriteria untuk mencapai ketiga tujuan utamanya, antara lain dapat dilihat pada Tabel 2.

Tabel 2. Kriteria Ruang yang Ramah (Sociable Place)

\begin{tabular}{|l|l|}
\hline \multicolumn{1}{|c|}{ Tujuan } & \multicolumn{1}{c|}{ Kriteria } \\
\hline Relaxation & $\begin{array}{l}\text { - Memberikan kenyamanan } \\
\text { (comfortably/friendly) }\end{array}$ \\
\hline Interaction & $\begin{array}{l}\text { - Interaktif (interactive) } \\
\text { - Menawarkan berbagai pilihan (diverse) }\end{array}$ \\
\hline Affiliation & $\begin{array}{l}\text { - Mengundang (inviting/welcoming) } \\
\text { - Kooperatif (cooperative) }\end{array}$ \\
& $\begin{array}{l}\text { - Memiliki istem penatalayanan bersama } \\
\text { (stewardship) } \\
\text { - Menjadi kebanggaan (pride) }\end{array}$ \\
\hline
\end{tabular}

Sumber: Penulis, 2021

Sementara Mehta (2013) menyatakan bahwa jalan sebagian besar merupakan tempat sosial bagi manusia, Pellegrini dan Baudry (2014) mencoba untuk merekonseptualisasikan jalan sebagai tempat baru bagi manusia dan alam. Selama ini, jalan telah diberi peran penting dalam tiap perencanaan jaringan hijau perkotaan di kota-kota padat. Pepohonan yang ada di jalan berkontribusi untuk meningkatkan kualitas udara perkotaan, menyerap air hujan, bertindak sebagai buffer lalu lintas di jalan, dan juga menghadirkan citra serta identitas yang kuat pada tempat tersebut karena daya tariknya (Halle, 2015; National Urban Forestry Unit, 2005; 
Smardon, 1988). Pohon di jalanan juga membantu menyediakan kanopi yang mendorong orang untuk berjalan di bawahnya (Jacobs, 1993; Sarkar et al., 2015).

\section{Metode Penelitian}

Sebagai penelitian kuantitatif dan kualitatif, penelitian ini memiliki kerangka teori penelitian yang terdiri dari dua hal, antara lain prinsip desain koridor hijau (green corridors) dan indikator ruang publik yang ramah (sociable public spaces). Metode pengumpulan data dan tahapan penelitian yang dilakukan adalah studi pustaka untuk memperoleh prinsip dan kriteria dari dua kerangka utama penelitian, dilanjutkan dengan analisis best practices untuk mendapatkan contoh implementasi dari prinsip desain koridor hijau, lalu melakukan observasi langsung atau survey lapangan terhadap kondisi fisik di wilayah penelitian dan menyebarkan kuesioner untuk mendapatkan persepsi masyarakat setempat terhadap potensi implementasi koridor hijau tersebut sebagai ruang terbuka hijau publik yang ramah (dengan setting kondisi sebelum pandemi Covid-19). Semua temuan utama data tersebut nantinya diterjemahkan ke dalam sebuah pedoman desain koridor hijau di wilayah penelitian.

Lokasi penelitian ini berada di salah satu kota padat di Indonesia, yakni Kota Malang, khususnya di jalan perniagaan yakni Jalan S.W. Pranoto, Jalan Sutan Syahrir, dan Jalan Pasar Besar, yang berada di dekat pasar tradisional bersejarah dan terbesar di Kecamatan Klojen, Kota Malang, bernama Pasar Besar (Gambar 1). Selain keberadaan pasar tradisional ternama tersebut, berbagai gerai ritel menjadi daya tarik utama ruas jalan ini. Karakter lokasi studi kasus tersebut menjadi acuan dalam memilih best practices koridor hijau di kawasan komersial, antara lain berlokasi di kota padat (atau minimal di kawasan padat) dan dalam skala yang kurang lebih sama dengan lokasi desain yang dipilih. Hasilnya, Jalan Hornsgatan (Stockholm, Swedia), Jalan Garibaldi (Lyon, Prancis), dan Jalan Barracks Row (Washington, D.C, USA) dipilih sesuai kriteria tersebut. Best practices tersebut dianalisis dalam konteks implementasi prinsip desain koridor hijau. Selanjutnya, hasil temuan analisisnya akan diterjemahkan ke dalam kuesioner yang disebarkan secara online melalui Google Forms kepada 100 responden masyarakat yang berdomisili di Kota Malang (random sampling).

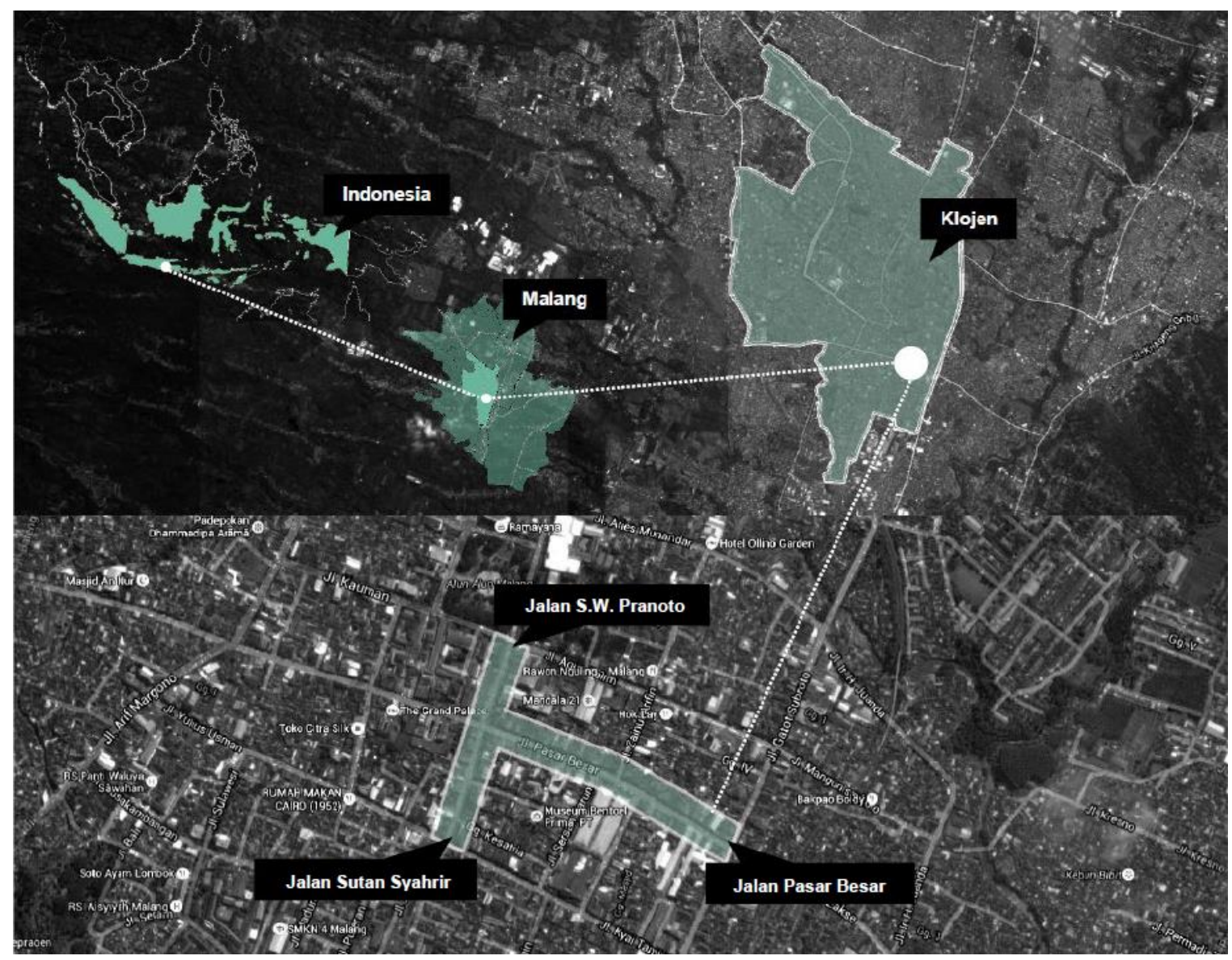

Gambar 1. Lokasi Wilayah Penelitian

Sumber: Penulis, 2021 


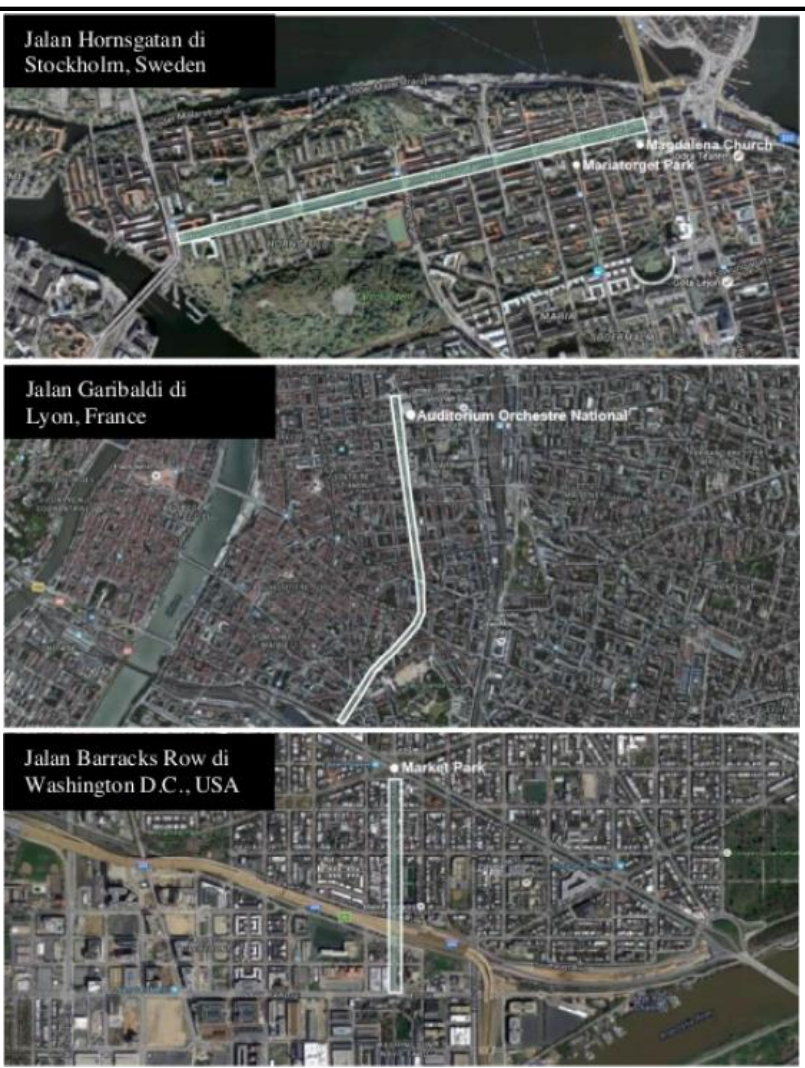

Gambar 2. Lokasi Best Practices

Sumber: Penulis, 2021

\section{Hasil dan Pembahasan}

\subsection{Analisis Best Practices}

Analisis terhadap best practices ditinjau berdasarkan implementasi prinsip desain dari koridor jalan atau jalur hijau, sehingga dapat dirumuskan practical design solutions dari setiap prinsip yang antara lain dapat dilihat pada Tabel 3 .

Tabel 3. Implementasi Prinsip Desain Koridor Hijau pada Best Practices

\begin{tabular}{|c|c|c|c|c|}
\hline \multirow[b]{2}{*}{ Prinsip } & \multicolumn{3}{|c|}{ Implementasi Prinsip Desain } & \multirow{2}{*}{ Hasil Temuan } \\
\hline & Jalan Hornsgatan & Jalan Garibaldi & Jalan Barracks Row & \\
\hline Naturalization & $\begin{array}{l}\text { - Menghubungkan beberapa } \\
\text { ruang terbuka hijau: }\end{array}$ & $\begin{array}{l}\text { Menghubungkan beberapa } \\
\text { ruang terbuka hijau: } \\
\text { Dua layer tanaman } \\
\text { (penanaman di tanah dan } \\
\text { pohon); beberapa jenis } \\
\text { tanaman (tiap jenis } \\
\text { berjumlah 10\% dari }\end{array}$ & $\begin{array}{l}\text { - Menghubungkan beberapa } \\
\text { ruang terbuka hijau: } \\
\text { - Tiga layer tanaman } \\
\text { (penanaman di tanah, } \\
\text { pohon, dan pot tanaman } \\
\text { fleksibel); beberapa jenis } \\
\text { tanaman. } \\
\text { - Menggunakan metode } \\
\text { penanaman strip selebar } 5 \\
\text { (lima) kaki sebagai } \\
\text { pengumpul air hujan. }\end{array}$ & $\begin{array}{l}\text { Membawa elemen alam } \\
\text { (hijau) ke jalan perlu } \\
\text { menciptakan konektivitas } \\
\text { secara ekologis dan } \\
\text { terhubung dengan ruang } \\
\text { terbuka hijau di sekitarnya. } \\
\text { Menggunakan satu atau } \\
\text { beragam jenis tanaman untuk } \\
\text { meningkatkan citra koridor } \\
\text { dan dapat berupa vegetasi } \\
\text { yang ditanam secara } \\
\text { permanen atau fleksibel } \\
\text { (dipindah-pindah) pada satu } \\
\text { atau lebih layer. } \\
\text { Menyediakan sistem } \\
\text { pengolahan air yang } \\
\text { sederhana di jalan } \\
\text { perniagaan yang ramai } \\
\text { dengan tetap memperhatikan } \\
\text { kebutuhan ruang bagi } \\
\text { tanaman untuk tumbuh. }\end{array}$ \\
\hline
\end{tabular}




\begin{tabular}{|c|c|c|c|c|}
\hline$(\cup \Delta$ & & Aguspriyanti, Gree & orridors: Potensi peningka & $\begin{array}{l}\text { In ruang terbuka hijau publik } \\
\text { ume } 4 \text { - Nomor } 2 \text { - Juni } 2021\end{array}$ \\
\hline \multirow[b]{2}{*}{ Prinsip } & \multicolumn{3}{|c|}{ Implementasi Prinsip Desain } & \multirow[b]{2}{*}{ Hasil Temuan } \\
\hline & Jalan Hornsgatan & Jalan Garibaldi & Jalan Barracks Row & \\
\hline & $\begin{array}{l}\text { - Menggunakan structural soil } \\
\text { sebagai sistem manajemen } \\
\text { dan pengolahan air: }\end{array}$ & $\begin{array}{l}\text { keseluruhan area). } \\
\text { Menggunakan material } \\
\text { trotoar tembus/resap air. }\end{array}$ & & \\
\hline Health & $\begin{array}{l}\text { - Terdapat fasilitas pendukung } \\
\text { seperti jalur sepeda, taman } \\
\text { kota. } \\
\text { - Penanaman vegetasi di jalur } \\
\text { pejalan kaki. }\end{array}$ & $\begin{array}{l}\text { - Terdapat fasilitas } \\
\text { pendukung seperti jalur } \\
\text { sepeda, taman kota. } \\
\text { - Penanaman vegetasi di } \\
\text { jalur pejalan kaki dan di } \\
\text { antara jalur pesepeda dan } \\
\text { kendaraan bermotor. }\end{array}$ & $\begin{array}{l}\text { - Lebih menjaga kebersihan } \\
\text { lingkungan secara rutin. } \\
\text { - Penanaman vegetasi di } \\
\text { jalur pejalan kaki. }\end{array}$ & $\begin{array}{l}\text { Penyediaan elemen natural, } \\
\text { penambahan fasilitas } \\
\text { pendukung seperti taman, } \\
\text { dan secara berkala menjaga } \\
\text { kebersihan lingkungan } \\
\text { setempat. }\end{array}$ \\
\hline Regulatory & $\begin{array}{l}\text { - } \\
\text { Terdapat jalur pejalan kaki } \\
\text { selebar } 3 \mathrm{~m} \text {. } \\
\text { - Satu jalur pohon sepanjang } \\
\text { jalan. }\end{array}$ & $\begin{array}{l}\text { - Terdapat jalur pejalan } \\
\text { kaki selebar 12 m. } \\
\text { - Tiga jalur pohon } \\
\text { - sepanjang jalan. }\end{array}$ & $\begin{array}{l}\text { - Terdapat jalur pejalan kaki } \\
\text { selebar } 3 \mathrm{~m} \text {. } \\
\text { - Satu jalur pohon sepanjang } \\
\text { jalan. }\end{array}$ & $\begin{array}{l}\text { Pengurangan kebisingan lalu } \\
\text { lintas, pengaturan } \\
\text { pembayangan dan suhu dapat } \\
\text { berkontribusi dalam } \\
\text { memaksimalkan kenyamanan } \\
\text { melalui penempatan pohon } \\
\text { yang tepat atau signifikan } \\
\text { dan pelebaran jalur pejalan } \\
\text { kaki minimal } 3 \text { m (jika } \\
\text { memungkinkan). }\end{array}$ \\
\hline Singular & $\begin{array}{l}\text { - Memiliki desain streetscapes } \\
\text { yang atraktif melalui } \\
\text { penggunaan material } \\
\text { pavement yang unik sebagai } \\
\text { aksen. } \\
\text { - Memiliki ciri khas sebagai } \\
\text { koridor multifungsi (koridor } \\
\text { hijau dan jalur tranportasi). }\end{array}$ & $\begin{array}{l}\text { - Memiliki desain } \\
\text { streetscapes yang atraktif } \\
\text { melalui penanaman } \\
\text { beragam vegetasi dan } \\
\text { perbedaan level atau } \\
\text { ketinggian permukaan } \\
\text { tanah. } \\
\text { - Memiliki ciri khas } \\
\text { sebagai koridor } \\
\text { multifungsi (koridor } \\
\text { hijau dan jalur } \\
\text { tranportasi). }\end{array}$ & $\begin{array}{l}\text { - Memiliki desain } \\
\text { streetscapes yang atraktif } \\
\text { melalui penanaman } \\
\text { beragam vegetasi, street } \\
\text { furnitures, dan material } \\
\text { pavement yang unik } \\
\text { sebagai aksen. } \\
\text { - Memiliki ciri khas sebagai } \\
\text { koridor multifungsi } \\
\text { (koridor hijau dan jalur } \\
\text { tranportasi). }\end{array}$ & $\begin{array}{l}\text { Menciptakan koridor jalan } \\
\text { yang unik melalui penguatan } \\
\text { desain streetscapes seperti } \\
\text { membuat struktur atau } \\
\text { bentuk jalan yang khas dan } \\
\text { mendekorasinya dengan } \\
\text { street furnitures dan material } \\
\text { yang unik, serta penyediaan } \\
\text { beragam vegetasi. }\end{array}$ \\
\hline Accessibility & 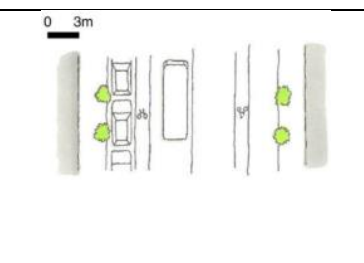 & - & ${ }^{0}{ }^{3 m}$ & $\begin{array}{l}\text { Memperhatikan tingkat } \\
\text { kenyamanan dalam } \\
\text { mengakses koridor jalan } \\
\text { dengan berbagai jenis } \\
\text { transportasi dan menghindari } \\
\text { konflik dengan elemen } \\
\text { natural yang ada di koridor } \\
\text { jalan tersebut. }\end{array}$ \\
\hline
\end{tabular}




\begin{tabular}{|c|c|c|c|c|}
\hline$\sqrt{\Delta}$ & $\begin{array}{l}\text { Jurnal } \\
\text { Arsitektur } \\
\text { Zzonasi } \\
\end{array}$ & \multicolumn{3}{|c|}{$\begin{array}{r}\text { Aguspriyanti, Green corridors: Potensi peningkatan ruang terbuka hijau publik } \\
\text { Volume 4-Nomor 2-Juni } 2021\end{array}$} \\
\hline \multirow{3}{*}{ Prinsip } & \multicolumn{3}{|c|}{ Implementasi Prinsip Desain } & \multirow{2}{*}{ Hasil Temuan } \\
\hline & Jalan Hornsgatan & Jalan Garibaldi & Jalan Barracks Row & \\
\hline & $\begin{array}{l}\text { Terdapat area khusus untuk } \\
\text { parkir kendaraan (paralel), } \\
\text { jalur pejalan kaki, pesepeda, } \\
\text { transportasi publik, dan } \\
\text { kendaraan bermotor lainnya. }\end{array}$ & $\begin{array}{l}\text { Terdapat area khusus untuk } \\
\text { jalur pejalan kaki, } \\
\text { pesepeda, transportasi } \\
\text { publik, dan kendaraan } \\
\text { bermotor lainnya, serta } \\
\text { fasilitas penyebrangan } \\
\text { jalan bagi pejalan kaki. }\end{array}$ & $\begin{array}{l}\text { Terdapat area khusus untuk } \\
\text { parkir kendaraan (paralel dan } \\
\text { serong), jalur pejalan kaki, } \\
\text { pesepeda, transportasi publik, } \\
\text { dan kendaraan bermotor } \\
\text { lainnya, serta fasilitas } \\
\text { penyebrangan jalan bagi } \\
\text { pejalan kaki. }\end{array}$ & \\
\hline Diversity & 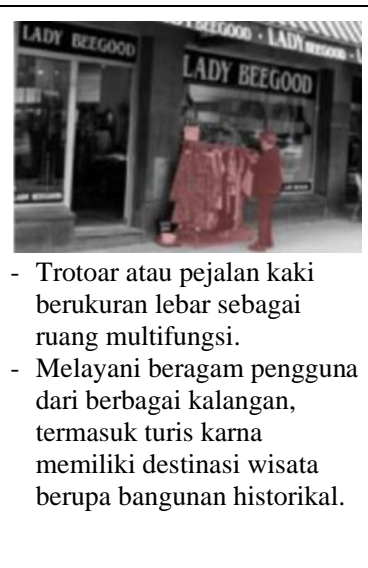 & $\begin{array}{l}\text { - Trotoar atau pejalan kaki } \\
\text { berukuran lebar sebagai } \\
\text { ruang multifungsi. } \\
\text { - Keberadaan Auditorium } \\
\text { Orchestre National } \\
\text { membantu menarik } \\
\text { beragam pengunjung. }\end{array}$ & $\begin{array}{l}\text { Trotoar atau pejalan kaki } \\
\text { berukuran lebar dan jalur } \\
\text { kendaraan sebagai ruang } \\
\text { multifungsi. } \\
\text { - Adanya kegiatan-kegiatan } \\
\text { publik seperti komersial } \\
\text { dan rekreasional (temporer) } \\
\text { membantu menarik } \\
\text { beragam pengunjung. }\end{array}$ & $\begin{array}{l}\text { Penyediaan ruang } \\
\text { multifungsi yang } \\
\text { memberikan kesempatan } \\
\text { untuk melakukan beragam } \\
\text { aktivitas dinilai penting } \\
\text { untuk dapat melayani } \\
\text { beragam kalangan } \\
\text { masyarakat (social diversity) } \\
\text { Memberikan lebih banyak } \\
\text { pilihan destinasi yang dapat } \\
\text { dinikmati membantu } \\
\text { menarik beragam } \\
\text { pengunjung. }\end{array}$ \\
\hline $\begin{array}{l}\text { Informative/ } \\
\text { Educational }\end{array}$ & $\begin{array}{l}\text { Menginformasikan citra kota } \\
\text { melalui karakter koridor jalan } \\
\text { yang kuat. }\end{array}$ & $\begin{array}{l}\text { Menginformasikan citra } \\
\text { kota melalui karakter } \\
\text { koridor jalan yang kuat. }\end{array}$ & $\begin{array}{l}\text { Adanya diskusi dengan } \\
\text { masyarakat setempat dalam } \\
\text { proses pengembangan } \\
\text { koridor jalan menambah } \\
\text { ketertarikan dan memperluas } \\
\text { wawasan masyarakat terkait } \\
\text { koridor hijau. }\end{array}$ & $\begin{array}{l}\text { Mengakomodasi kebutuhan } \\
\text { masyarakat setempat dan } \\
\text { memberikan edukasi adalah } \\
\text { hal yang esensial demi } \\
\text { keberlanjutan koridor hijau. } \\
\text { Peningkatan identitas kota } \\
\text { dapat dilakukan melalui } \\
\text { penyediaan koridor hijau } \\
\text { yang memiliki karakter yang } \\
\text { kuat. }\end{array}$ \\
\hline
\end{tabular}

Sumber: Penulis, 2021

\subsection{Analisis Kondisi Eksisting dan Persepsi Masyarakat}

Hasil observasi lapangan menunjukkan bahwa kondisi fisik Jalan S.W. Pranoto, Jalan Sutan Syahrir, dan Jalan Pasar Besar masih kurang mendukung baik pengguna maupun elemen alam (vegetasi) yang ada di sana. Jika mengacu pada peraturan pemerintah setempat, koridor jalan ini termasuk dalam rencana penyediaan green network di kota Malang. Namun pada kenyataannya, masih ada bagian jalan yang merupakan missing network dengan artian belum memiliki penghijauan, yakni di Jalan Pasar Besar (Gambar 3).

Selain itu, hampir di seluruh bagian ketiga jalan tersebut belum memiliki jalur pedestrian yang didukung dengan street furnitures yang memadai, seperti kursi, lampu, dan sebagainya. Media tanam pohon yang ada sekarang pun belum ideal. Permasalahan lainnya adalah jalur pedestrian yang digunakan sebagai tempat berjualan dan parkir di beberapa titik, belum adanya area khusus untuk parkir kendaraan di sebagian jalan, jalur khusus untuk transportasi publik. pesepeda, dan kendaraan pribadi, serta sarana penyeberangan jalan yang mencukupi (hanya ada di beberapa titik lokasi). Di sisi lain, ketiga jalan tersebut belum memiliki karakter atau identitas yang cukup kuat. Permasalahan-permasalahan dari kondisi eksisting tersebut dapat dilihat pada Gambar 4. 


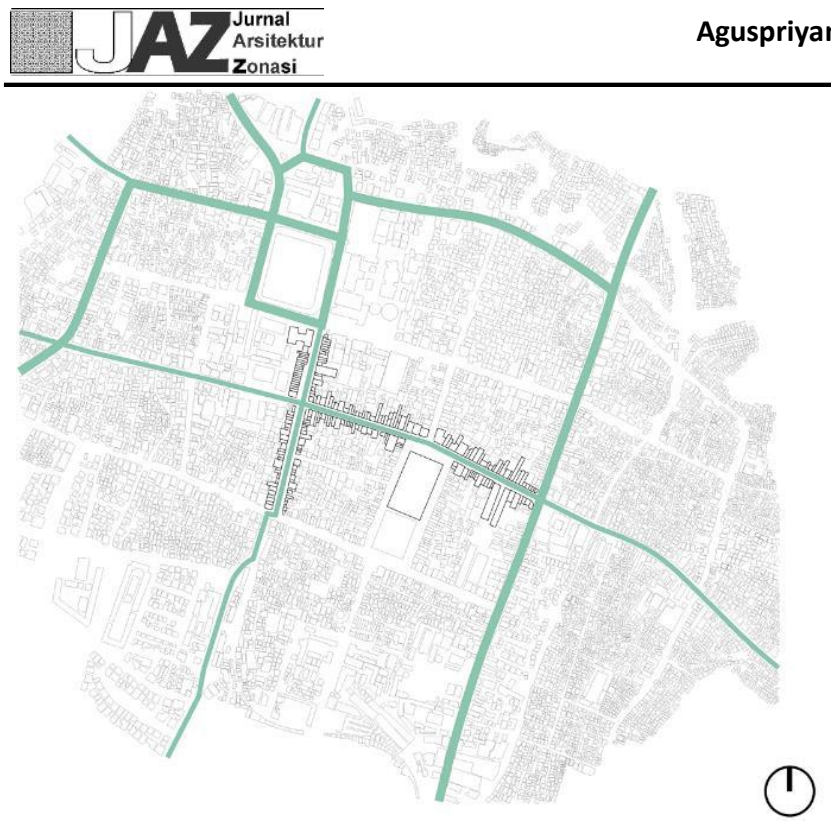

Gambar 3. Kiri: Rencana Pengembangan Green Network Kota Malang; Kanan: Missing Network

Sumber: Penulis, 2021

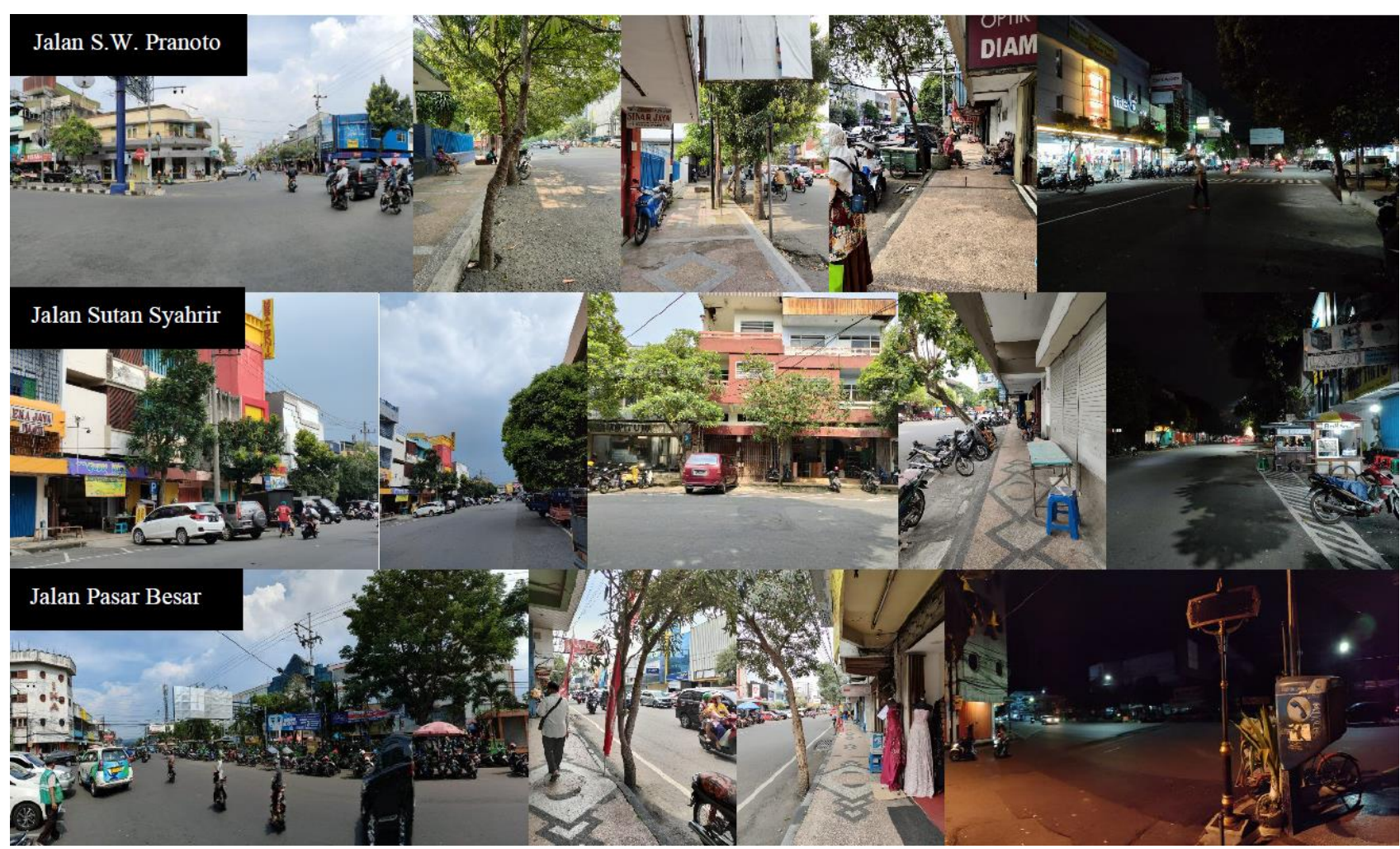

Gambar 4. Kondisi Eksisting Wilayah Penelitian

Sumber: Penulis, 2021

Jika dibandingkan dengan masa sebelum pandemi Covid-19, aktivitas di tiga koridor jalan ini terpantau cenderung tidak lebih ramai, sehingga mungkin akan ada perbedaan persepsi masyarakat terhadap prioritas penggunaan koridor jalan ini. Responden yang $100 \%$ berdomisili di Malang dan mayoritas merupakan lakilaki (51\%) serta memiliki rentang usia 15-34 tahun (69\%) ini memilih 'interaction' sebesar 63\% sebagai prioritas atau tujuan utama koridor hijau sebagai RTH publik sebelum masa pandemi Covid-19, disusul dengan 'relaxation' sebesar $20 \%$ di posisi kedua dan 'affiliation' sebesar $17 \%$ di posisi ketiga. Sehingga dapat dikatakan bahwa dalam menjalankan perannya sebagai RTH publik yang ramah (sociable), koridor hijau untuk saat sebelum pandemi Covid-19 menitikberatkan pada memfasilitasi aktivitas bersosialisasi penggunanya.

Dalam upaya memfasilitasi ketiga aspek RTH publik yang ramah tersebut sembari meningkatkan RTH publik yang ada di Kota Malang baik secara kualitas maupun kuantitas, masyarakat memiliki persepsi bahwa penerapan prinsip-prinsip desain koridor hijau dapat mempengaruhi tingkat keramahan di ketiga koridor jalan perniagaan di Kota Malang (Tabel 4). 
Tabel 4. Tingkat Pengaruh Prinsip Desain Koridor Hijau Terhadap Kriteria Ruang Publik yang Ramah Berdasarkan Persepsi Masyarakat Kota Malang

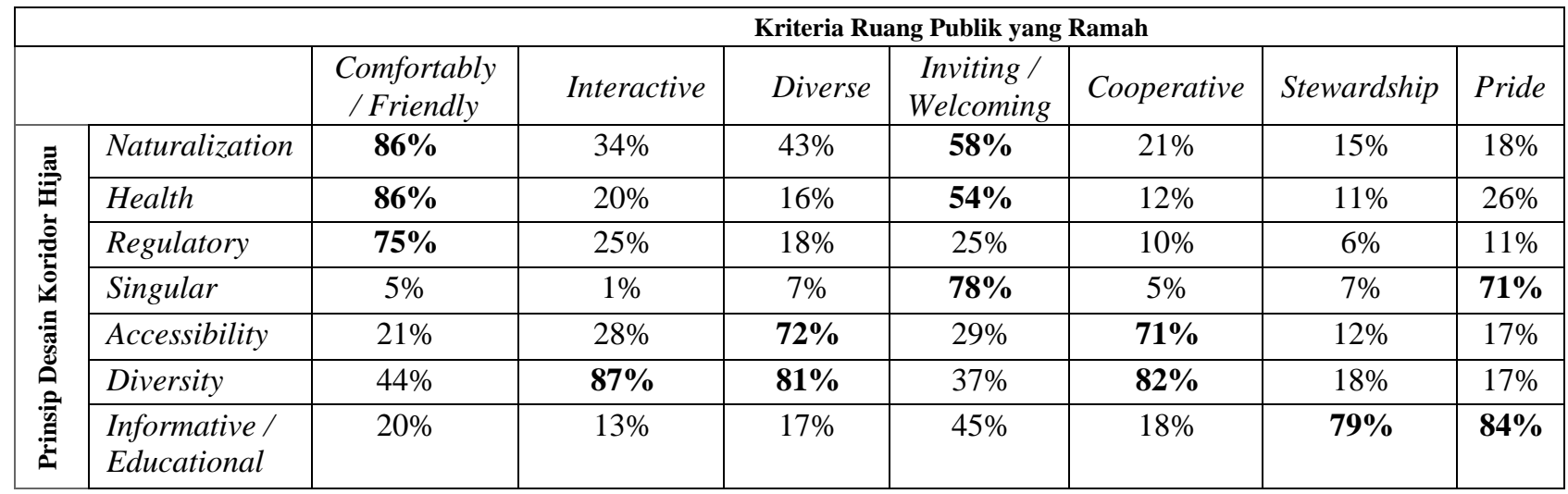

Sumber: Penulis, 2021

\subsection{Usulan Pedoman Desain Koridor Hijau}

Hasil analisis terhadap best practices, kondisi eksisting, dan persepsi masyarakat, dapat disintesis menjadi sebuah usulan pedoman desain koridor hijau di ketiga koridor jalan terpilih yang dapat dilihat pada Tabel 5.

Tabel 5. Usulan Pedoman Desain Koridor Hijau sebagai RTH Publik Ramah

\begin{tabular}{|c|c|c|}
\hline $\begin{array}{l}\text { Kriteria Ruang } \\
\text { Publik Ramah }\end{array}$ & Prinsip Desain Koridor Hijau & Strategi Desain \\
\hline & \multicolumn{2}{|l|}{ Naturalization } \\
\hline $\begin{array}{l}\text { Comfortably / } \\
\text { Friendly }\end{array}$ & $\begin{array}{l}\text { - Menciptakan konektivitas } \\
\text { ekologis } \\
\text { - Membawa elemen alam (hijau) } \\
\text { ke jalan } \\
\text { - Menciptakan berbagai lapisan } \\
\text { vegetasi } \\
\text { - Membawa keanekaragaman } \\
\text { tumbuhan } \\
\text { - Menyediakan sistem pengolahan } \\
\text { air yang memastikan ruang } \\
\text { tumbuh memadai bagi tumbuhan } \\
\text { setempat } \\
\end{array}$ & $\begin{array}{l}\text { Continuity } \\
\text { Menyediakan konektivitas elemen hijau yang saling } \\
\text { terhubung antara site dan sekitarnya (green network). } \\
\text { Multilayers } \\
\text { Menambahkan elemen hijau pada dinding bangunan } \\
\text { dan jalan untuk memastikan visibilitas dari papan } \\
\text { toko; menggunakan beragam vegetasi yang dapat } \\
\text { diatur secara fleksibel dan permanen; menerapkan } \\
\text { sistem pengolahan air sederhana (di bawah dan di } \\
\text { permukaan tanah) yang terintegrasi baik dengan } \\
\text { ruang tumbuh akar. }\end{array}$ \\
\hline & \multicolumn{2}{|l|}{ Health } \\
\hline $\begin{array}{l}\text { Interactive } \\
\text { Diverse }\end{array}$ & $\begin{array}{l}\text { - Menciptakan area terapeutik } \\
\text { - Menjaga kebersihan }\end{array}$ & $\begin{array}{l}\text { Pocket parks } \\
\text { Mendesain taman kecil di beberapa titik lokasi yang } \\
\text { memungkinkan dan menghadap jalan. } \\
\text { Furniture addition } \\
\text { Menambahkan perabot jalan (street furnitures) } \\
\text { seperti tempat sampah untuk meminimalisir } \\
\text { pembuangan sampah sembarangan. }\end{array}$ \\
\hline & \multicolumn{2}{|l|}{ Regulatory } \\
\hline $\begin{array}{l}\text { Welcoming } \\
\text { Cooperative }\end{array}$ & $\begin{array}{l}\text { - Memberikan efek ketenangan } \\
\text { - Memaksimalkan kenyamanan }\end{array}$ & $\begin{array}{l}\text { Wider sidewalks } \\
\text { Memperlebar trotoar untuk memberikan ruang yang } \\
\text { lebih lapang bagi pejalan kaki. } \\
\text { Informal seating } \\
\text { Mendesain tempat tanaman (planter boxes) yang } \\
\text { dapat difungsikan sebagai tempat duduk juga. }\end{array}$ \\
\hline & \multicolumn{2}{|l|}{ Singular } \\
\hline Stewardship & $\begin{array}{l}\text { - Menghadirkan lanskap menarik } \\
\text { yang dapat dinikmati secara } \\
\text { visual maupun fisik, serta mudah } \\
\text { diidentifikasi } \\
\text { - Memaksimalkan kenyamanan }\end{array}$ & $\begin{array}{l}\text { Distinct gateways } \\
\text { Mendesain area masuk dan keluar kawasan yang } \\
\text { menarik untuk meningkatkan kualitas citra jalan. } \\
\text { Unified decoration } \\
\text { Menerapkan desain paving yang unik; memilih } \\
\text { tanaman lokal yang menarik; menambahkan perabot }\end{array}$ \\
\hline
\end{tabular}




\begin{tabular}{|c|c|c|}
\hline $\begin{array}{l}\text { Kriteria Ruang } \\
\text { Publik Ramah }\end{array}$ & Prinsip Desain Koridor Hijau & Strategi Desain \\
\hline \multirow{7}{*}{$\begin{array}{l}\text { (Tiap kriteria ruang } \\
\text { publik ramah dapat } \\
\text { dipengaruhi oleh } \\
\text { prinsip desain } \\
\text { koridor hijau } \\
\text { tertentu sesuai } \\
\text { dengan kode warna) }\end{array}$} & & $\begin{array}{l}\text { jalan (street furnitures) seperti lampu dan public arts } \\
\text { yang atraktif. }\end{array}$ \\
\hline & \multicolumn{2}{|l|}{ Accessibility } \\
\hline & $\begin{array}{l}\text { - Menawarkan banyak pilihan } \\
\text { transportasi publik (jika } \\
\text { memungkinkan) dan mencegah } \\
\text { konflik antara pengguna dan } \\
\text { elemen alam di jalan setempat } \\
\text { - Menyediakan fasilitas yang } \\
\text { memadai untuk mendorong } \\
\text { berjalan kaki, bersepeda, dan } \\
\text { penggunaan transportasi publik }\end{array}$ & $\begin{array}{l}\text { Dedicated lanes } \\
\text { Mengalokasikan jalur khusus untuk tipe transportasi } \\
\text { tertentu seperti transportasi publik, sepeda, dan } \\
\text { sebagainya di beberapa titik lokasi yang } \\
\text { memungkinkan. } \\
\text { Central reservation } \\
\text { Menambahkan median jalan yang multifungsi } \\
\text { sebagai tempat menyebrang di beberapa titik lokasi } \\
\text { yang memungkinkan. }\end{array}$ \\
\hline & \multicolumn{2}{|l|}{ Diversity } \\
\hline & $\begin{array}{l}\text { - Memberi ruang untuk beragam } \\
\text { kegunaan } \\
\text { - Melayani beragam lapisan } \\
\text { masyarakat (social diversity) } \\
\text { dengan menyediakan destinasi- } \\
\text { destinasi menarik }\end{array}$ & $\begin{array}{l}\text { Shared street } \\
\text { Mengalokasikan satu koridor jalan sebagai jalan } \\
\text { bersama yang bisa digunakan oleh pejalan kaki di } \\
\text { malam hari untuk melakukan kegiatan temporer, } \\
\text { misalnya pasar kuliner malam, untuk menarik } \\
\text { pengunjung. } \\
\text { Multi-uses sidewalks } \\
\text { Membagi trotoar menjadi dua area (satu untuk lalu } \\
\text { lalang dan satu untuk aktivitas lainnya) guna } \\
\text { memfasilitasi beragam kegiatan dengan minim } \\
\text { konflik antar pejalan kaki. }\end{array}$ \\
\hline & \multicolumn{2}{|l|}{ Informative / Educational } \\
\hline & $\begin{array}{l}\text { - Menumbuhkan minat terhadap } \\
\text { alam } \\
\text { - Meningkatkan citra atau } \\
\text { menambah identitas kota }\end{array}$ & $\begin{array}{l}\text { Native plants } \\
\text { Menanam tanaman lokal untuk memperkuat citra } \\
\text { koridor jalan dan kota. } \\
\text { Community engagement } \\
\text { Melibatkan masyarakat setempat dalam proses } \\
\text { perencanaan, pelaksanaan, dan pengelolaan. }\end{array}$ \\
\hline
\end{tabular}

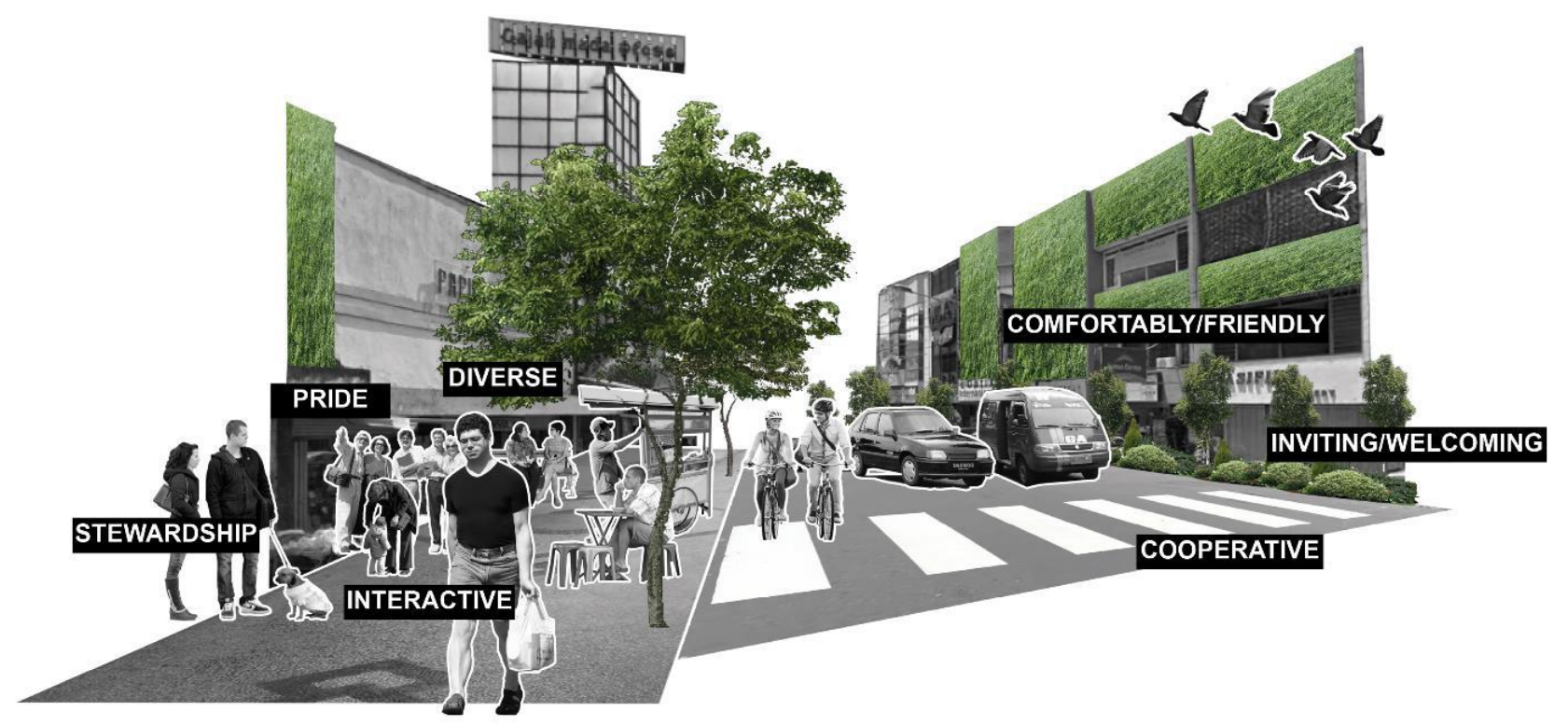

Gambar 5. Konsep Usulan Desain Koridor Hijau Sebelum Pandemi Covid-19 Sumber: Penulis, 2021 


\section{Kesimpulan}

Penelitian ini menemukan bahwa green corridors atau koridor hijau berpotensi menjadi ruang terbuka hijau publik yang ramah sekaligus memainkan peran penting dalam meningkatkan cakupan ruang hijau di perkotaan yang padat. Khususnya, pada kasus koridor jalan perniagaan di Kota Malang, beberapa implementasi prinsip desain koridor hijau yang didapat dari kajian literatur dan best practices, dinilai memiliki pengaruh yang signifikan terhadap kriteria tertentu dari ruang publik yang ramah. Hal ini didasari oleh persepsi masyarakat setempat. Hasil-hasil temuan tersebut kemudian diterjemahkan bersama menghasilkan usulan pedoman desain koridor hijau yang dapat menjawab permasalahan yang ditemukan dari observasi kondisi eksisting. Strategi desain dalam usulan pedoman tersebut yakni continuity, multilayers, pocket parks, furniture addition, wider sidewalks, informal seating, distinct gateways, unified decoration, dedicated lanes, central reservation, shared street, multi uses sidewalks, native plants, dan community engagement. Namun, penelitian ini mengulik kondisi sebelum pandemi Covid-19, sehingga diperlukan penelitian lanjutan terkait dampak Covid-19 terhadap penggunaan ruang terbuka hijau publik. Karena hal tersebut akan mempengaruhi usulan desain koridor hijau secara umum.

\section{Ucapan Terima Kasih}

Ucapan terima kasih disampaikan kepada semua pihak, khususnya Universitas Internasional Batam selaku penyedia dana penelitian, yang telah membantu dan memberikan kesempatan untuk melaksanakan penelitian ini.

\section{Referensi}

Byrne, J., dan Rupprecht, C. (2014). Our Cities Need More Green Spaces for Rest. http://theconversation.com/our-cities-need-more-green-spaces-for-rest-and-play-heres-how-28271

Carmona, M., Heath, T., Oc, T., dan Tiesdell, S. (2003). Public Places Urban Spaces: The Dimensions of Urban Design. Architectural Press. http://www.elsevier.com

Das, N. (2006). Green Streets - An Innovative Street Design Approach. Sustainability and Built Environment. $\mathrm{http} / / / \mathrm{www}$. portlandonline.com/bes/index.cfm?c=degab

Everett, G., Lamond, J. E., Morzillo, A. T., Matsler, A. M., dan Chan, F. K. S. (2018). Delivering Green Streets: an exploration of changing perceptions and behaviours over time around bioswales in Portland, Oregon. Journal of Flood Risk Management. https://doi.org/10.1111/jfr3.12225

Groome, D. (1990). "Green Corridors": A Discussion of A Planning Concept. Landscape and Urban Planning, $19,383-387$.

Halle, F. (2015). Le Charte De L'arbre: Building A New Shared Urban Culture Together. http://blogs.grandlyon.com/developpementdurable/en-actions/dispositifs-

Jacobs, A. B. (1993). Great Streets. Cambridge: MIT Press. MIT Press.

Jenks, M., \& Jones, C. (2010). Dimensions of the Sustainable City. In Media.

Lukes, R., Kloss, C., \& L.I.D.C. (2008). Managing Wet Weather with Green Infrastructure; Municipal Handbook: Green Streets. Low Impact Development Center.

Mehta, V. (2013). The street: A quintessential social public space. In The Street: A Quintessential Social Public Space. https://doi.org/10.4324/9780203067635

Mordon, A. V. (1987). Public Streets for Public Use. Colombia University Press.

National Urban Forestry Unit. (2005). Trees Matter! Bringing Lasting Benefits to People in Towns.

Pellegrini, P., dan Baudry, S. (2014). Streets as new places to bring together both humans and plants: examples from Paris and Montpellier (France). Social and Cultural Geography, 15(8), 871-900. https://doi.org/10.1080/14649365.2014.974067

Perry, K. (2010). Green Infrastructure Planning and Design: Green Streets, Parking Lots, and Other Public Places. $\operatorname{lgc}$. org/wordpress/docs/events/greening_communities_sjv/gcsjv_perry.pdf

Project for Public Spaces. (n.d.). What Makes a Successful Place? https://www.pps.org/article/grplacefeat

Sarkar, C., Webster, C., Pryor, M., Tang, D., Melbourne, S., Zhang, X., \& Jianzheng, L. (2015). Exploring associations between urban green, street design and walking: Results from the Greater London boroughs. Landscape and Urban Planning, 143, 112-125. https://doi.org/10.1016/j.landurbplan.2015.06.013

Säumel, I., Weber, F., dan Kowarik, I. (2016). Toward livable and healthy urban streets: Roadside vegetation provides ecosystem services where people live and move. Environmental Science and Policy, 62, 24-33. https://doi.org/10.1016/j.envsci.2015.11.012

Smardon, R. C. (1988). Perception and Aesthetics of the Urban Environment: Review of the Role of 
Vegetation. Landscape and Urban Planning, 15, 85-106.

The Nature of Cities. (2014). Do Urban Green Corridors "Work"? It Depends on What We Want Them to Do. What Ecological and/or Social Functions Can We Realistically Expect Green Corridors to Perform in Cities? What Attributes Define Them, From a Design and Performance Perspective? $\mathrm{http}: / / \mathrm{www}$.thenatureofcities.com/2014/10/05/do-urban-green-corridors-work-it-depends-on-what-wewant-them-to-do-what-ecological-andor-social-functions-can-we-realistically-expect-green-corridorsto-perform-in-cities-what-attributes-defi/\#

Viles, R. L., dan Rosier, D. J. (2001). How to use roads in the creation of greenways: case studies in three New Zealand landscapes. Landscape and Urban Planning, 55, 15-27.

Wolf, K. L. (2005). Business District Streetscapes, Trees, and Consumer Response. Journal of Forestry, $103(8), 396-400$. 